\title{
A critical evaluation of causalities of the genocide in Esther 3:8-15: Lawlessness and revolt of the Jewish diaspora community
}

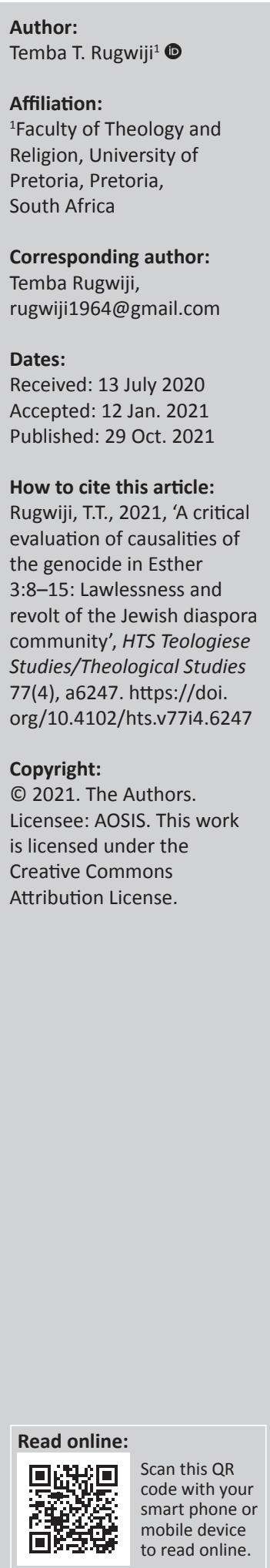

Rereading of Esther 3:8-15 depicts that lawlessness and revolt on the part of the Jewish diaspora community ignited the genocide in the Persian Empire. The narrative is explicit that Haman was not comfortable with two main issues concerning the Jews: (1) their laws were different from those of every other people and (2) they did not keep the king's laws. In addition, some Jewish individuals were disrespectful to Persian superiors: Mordecai refused to bow down to Haman. Following Haman's report, Emperor Xerxes endorsed the proposition of exterminating the Jews as a possible solution. The present study argues against a populist view that puts Haman in a bad light. Existing studies on the genocide narrative in Esther 3:8-15 appear to sympathise with the Jewish diaspora community in Persia in spite of their attitude that portrayed some rebellious tendencies. Examined from a security and defence perspective, Haman's position should be given its merit because the Jews disobeyed the Persian laws and did not show respect to the Persian authorities. The study employs a narrative approach to argue that the Jewish diaspora community orchestrated the genocide by disobeying the Persian laws. It is further argued that Haman had correctly foreseen it coming and confided with Emperor Xerxes. The study will also discuss Haman as a strategist who speculated a possible Jewish revolt, which was confirmed by the massacre of 75000 people including Haman's children (9:1-10). This study will present to the academic readership a new dimension of reading Esther 3:8-15.

Contribution: Previous studies variously provided some magnanimity on the book of Esther. The contribution of the present study to the readership and the academic community seeks to suggest a new reading of the book by arguing that the Jews provoked the Persian authorities by disobeying the laws of the land.

Keywords: genocide; Jewish diaspora community; lawlessness; Persia; revolt.

\section{Introduction}

In the ancient Near East (ANE) and during biblical times, people used to move from one place to another either to buy food, for trade or as merchants (cf. Gn 26:3; 37:28; 42:1-3; $1 \mathrm{Ki} \mathrm{5:1-18).}$ Human movement from areas of social and economic distress to those with better prospects for survival and self-actualisation has continued unabated (Isike \& Isike 2012:93). The Persian Empire comprised over 127 provinces, including India and Ethiopia, and the capital was Susa where Emperor Xerxes had his throne (Es 1:1). According to Haman, the Jews comprised a major part of the population of Persian provinces. It can be speculated that Haman was both a strategist and a political analyst who foresaw the risks that lay ahead when the population of the Jews continued to increase, accompanied by a deliberate ignorance to observe the laws of the Empire. In Haman's view, it was highly likely that the natives of Persia would be overpowered in the event of a revolt by the Jews. Haman had also predicated an uprising by the Jews who adhered to their own laws and not the laws of the empire. Haman's fear was confirmed by the massacre of a total of 75000 people, including Haman's children. Thus, Snyman (2014) could not have missed it to state that:

In the Book of Esther, it is very clear that the Jews towards the end of the story became like their oppressors. In order to survive the Jewish people had to do what Haman intended to befall on them. (p. 660)

Although Duguid (2006:85) posited that 'Fundamental conflict between the heavenly order and the earthly order underlies the whole narrative, from beginning to end', in contrast I analyse it differently. I read in the narrative of the Jewish people who did not follow the rules of the game by disobeying the laws of Persia, and when the empire applied its laws upon them, they appealed to the divine. For Mordecai to refuse 'to bow the knee to Haman' (Duguid 2006:90) was an act of revolt. On the one hand, for king Xerxes to be lenient on the Jews by reversing the edict he had administratively made with Haman was because of a conjugal relationship that Xerxes had 
established with Esther without even investigating the allegations of lawlessness and disobedience amongst the Jews. On the other hand, Esther took advantage of the status quo, which she manipulated successfully. Hence, Mckee (2009:6) could say: 'Esther's king might be judged as foolish as easily as she manipulated him into giving her what she wanted' (see also cf. Zaeske 2000:211). Of special note is the fact that the king did not consider the merit of the allegation of a possible Jewish revolt as a serious threat to national security. At the end of the narrative, the genocide claimed 75000 deaths (Wetzel 2015:4). We read of the same pattern in the exodus from Egypt in which the Israelites escaped enslavement and the Egyptians were drowned by the flood of the 'sea waters' (Ex 15; see also Klein 2012:517). In other writings, I alluded to the Deuteronomistic history (e.g. Adamo 2010:9-27; Römer 2007) ${ }^{1}$ that always portrayed the Israelites as superior and victorious over their enemies.

\section{Methodology}

This study utilises narrative inquiry as a qualitative approach (see Sandelowski 1991:161-166; White 1980). Narrative inquiry specifically suggests the utilisation of existing literature on the themes investigated in this discourse. Examples include: Beckman (2013), Duguid (2006), Jacobs (2008), Jones (1978), Mckee (2009), Snyman (2014) and Wetzel (2015). The narrative in the biblical book of Esther remains the primary source that informs the present research.

\section{Migration in ancient Israel}

Factors that led people to migrate to other parts of the ANE varied. People would move from one place to another because of famine, trade or commerce. In both Mesopotamia and Hatti the voluntary immigration of individuals or families was tolerated, whilst the incursion of armed groups was resisted, but the presence of certain classes of outsiders was actively encouraged by the leaders of society (Beckman 2013:205). Merchants were most prominent amongst foreigners in ANE (Leemans 1950). During ancient biblical times, slaves were also part of the migrant community. A slave was usually a foreigner bought from another country or a captive ( $\operatorname{Lv} 25: 44-45)$.

The biblical text narrates the story of Abram who sojourned to Egypt because of famine in Egypt (Gn 12:10). Joseph was sold as a slave by his brothers to Midianite traders for 20 shekels of silver (Gn 37:25-28). Later on Joseph - who was honoured by the Pharaoh and was now in charge of procurement of grain in Egypt and second to Pharaoh (Gn 41:40-44) - told his brothers: 'I am your brother Joseph whom you sold into Egypt' (Gn 45:4). The Bible further explains that 'famine was spread over all the face of the earth ...' (Gn 41:56), and that 'People of all the earth came to buy grain from Joseph ...' (Gn 41:57). This severe famine that also struck Canaan made Jacob, Joseph's father, to send his 10 sons 'to buy grain from Egypt' (Gn 42:3; 43:1-2). Finally, Jacob and his family together with their flocks and their 1.Deuteronomist history will be discussed in detail in a future study. herds migrated to the land of Goshen in Egypt (Gn 47:1-11). With the passage of time, Jacob's descendants were treated as slaves in Egypt (Ex 1:11-14; Dt 15:15; 16:12; 24:18), which resulted in the exodus through Moses.

King Solomon also levied forced labour from amongst the descendants of the Amorites, the Hittites, the Perizzites, the Hivites and the Jebusites (1 Ki 9:20; see also Bremer 2019:689). The Israelites were commanded by Yahweh to 'show your love for the alien, for you were aliens in the land of Egypt' (Dt 10:19). Yahweh allowed the Israelites to extract usury from a foreigner but not from a fellow Jew (Dt 15:3; 23:20).

Nehemiah's condemnation of usury was probably because it was exerted on fellow Jews (Buckley 2000:1). Sometimes wanted criminals or murderers also constituted a migrant population during ancient biblical times. For example, Moses ran away from Egypt to Midian after the realisation that the Egyptian King Pharaoh wanted him to be tried for murder (Ex 2:11-15). In Midian, Moses married Zipporah the daughter of Jethro, the priest (Ex 2:21). Moses also got himself a job of pasturing the flock of his father-in-law in Midian (Ex 3:1). The book of Esther also talks of Jewish immigrants in Persia.

\section{Exegesis of Esther 3:8-15}

The book of Esther tells the story of the deliverance of the Jews from extermination. Although the narrative differs from the Egyptian Exodus, one would see some resemblance in the two narratives in view of: (1) a community under subjugation and (2) the massacre of the natives. However, Esther 3:8-15 is a narrative about a young Jewish woman (Esther) and her uncle (Mordecai) who managed to secure the future of the Jewish people under the Persian Empire (Reid 2000:79). In 586/7 Before the Common Era (BCE), Jerusalem was besieged by the Babylonians, and numerous Jews were taken as captives to Babylonia. Some sources believe that the siege was a culmination of a long period of military threat, political treaties and internal tug of war between pro-Egyptian and pro-Babylonian Israelites (Boshoff 1991:184). In 539 BCE, the Persian king Cyrus ordered the return of the Jews to Judah. The right of the book of Esther to be included in the Bible has been attacked by many on the ground that the name of God does not appear in it (Humphreys 1973:21-23) and that there are no direct suggestions that the religious factors of faith or prayer $^{2}$ played any significant part in the movement of events. It is reported that even Martin Luther rejected the book (Reid 2000:80). Other critics have tried to make it a Babylonian legend picturing the conflict of the gods (Reid 2000:80). Esther is presented as a young, orphaned girl who is taken against her will from her home and forced to integrate into a foreign, alien world (Jacobs 2008:13). She stands the test honourably, maintaining her dignity and her modesty at every stage preceding her selection as queen (Jacobs 2008:13). Reid (2000) remarks that:

2.This concept will be discussed in detail in this study. 
The author of the book of Esther is not known. Reid further notes that the story is set in the reign of King Xerxes (486-465 BCE). During this time, some of the exiled Jews returned to Jerusalem, but others remained in Mesopotamia under Persian rule. The Jews who remained were aware that their position was tenuous because Haman was determined to destroy the Jewish people. The book of Esther has many parallels to the exodus story. In the exodus, Yahweh heard the cry of his oppressed people in Egypt (Ex. 6:5), now he hears the wailing of his people facing the terror of Haman (Est. 4:1-3). (pp. 80-81)

The empire of Xerxes was co-opted by Haman to spread the decree to eliminate Mordecai's people. Esther co-operates with Mordecai and plays a crucial part in saving the Jews (Duguid 2006:90). Gerleman (1966) concurred that:

All the essential features of the Esther narrative are already there in Exodus 1-12: the foreign court, the mortal threat, the deliverance, the revenge, the triumph, and the establishment of a festival. (p. 11)

The given assertion renders the view that the author of Esther had the exodus tradition in mind. Duguid (2006:90) says that the book of Esther presents that the potent resources of the empire of Xerxes were co-opted by Haman to spread the decree to eliminate Mordecai's people (Es 3:9-15). One may ask: What were Haman's accusations against the Jews which influenced a plot to destroy them? This essay will analyse Haman's accusations in view of their negative impact on Persian citizens. Duguid (2006:90) affirmed that the charge that Haman brought against the Jews was that the latter kept to themselves and did not obey the empire's laws (Es 3:8). Put in other ways, the statement 'they kept to themselves' (Es 3:8a) would mean the Jews did not associate with the Persians. In my view, 'they kept to themselves' does not present a direct negative impact on the lives of Persian communities for Jews to deserve extermination. Let us examine Mordecai's disregard of King Xerxes' law by not bowing to Haman and the law regarding the Jews and their relationship with Yahweh. The Bible depicts the notion that Israel is the believing community of Yahweh (Rugwiji 2014:296). The declaration in Deuteronomy 17:15 that: 'Do not place a foreigner over you (as king), one who is not a brother Israelite', reinforces the argument that the Jews in exile would not identify themselves with either a pagan king or local communities. Esther 3:8b can be read in view of the king's command in 3:2, which states that: 'All the king's servants who were within the king's gate bowed and paid homage to Haman' (Es 3:2a). However, that Mordecai did not bow or pay homage (Es 3:2b), kindled Haman's wrath (Es 3:5). The other servants - who were probably Persians had told Haman that Mordecai was a Jew and would not bow to him (Es 3:4). We also read that Shadrach, Meshach and Abednego would not bow down or worship the gold image, which was set up by King Nebuchadnezzar (Dn 3:15). One has to understand Mordecai's rude behaviour in view of the Jewish religion, which was exclusively monotheistic (Rugwiji 2014:296). The Torah prohibits a Jew to bow to anything or anyone but Yahweh (Ex 23:24). If Mordecai knew this God of the Torah whose laws he obeyed, why does the book of Esther not mention God? In contrast, we read about Shadrach,
Meshach, Abednego and Daniel (Dn 3:17; 6:22) explicitly mentioning the name of God who they believed would deliver them from the furnace of fire and the den of lions, respectively. Added to this view is Mordecai's statement of 'from another quarter' (Es 4:14), which suggests that he believed in divine powers other than Yahweh's. For disregarding the king's law, Haman did not do anything against Mordecai until an opportune time (Es 4:6). Haman came to realise that the Jewish law and the king's law were different (Es 4:8). However, Haman was still determined to destroy the Jews. Haman's determination to destroy the Jews was authenticated by his commitment by offering a 'bribe' of 10000 talents towards payment 'of those who do the work' (Es 3:9). Verses 10-15 are narratives about procedures on authenticating the genocide. Jones (1978:39) observed that the reference to the pur in 3:7 is an integral part of the story, but its significance is not clear without 9:26 where the explanation of the name Purim is given. It is stated that without that ending, the first reference to the pur makes no sense and the book would have lost one of its reasons for being (Jones 1978:39). Pur was conducted by Haman and his accomplices from the month of Nisan (1st month) until the month of Adar (the 12th month; see Es 9:26) as part of the planning for exterminating the Jews. Littman (1975) affirmed that:

According to the book of Esther the festival of Purim, which occurs on the 14th day of Adar commemorates the escape of the Persian Jews from the death, which the vizier Haman had planned for them. (p. 145)

It has to be noted that whilst the date for execution of Haman's plot was decided by a lot (Pur), which is Persian, the author of Esther decides to use the term Purim for the Jewish festival. Esther 9:26, 'So they called these days Purim, after the name Pur', clearly illustrates that it was the time during which the Jews were contemplating the fate of the Persians. This authenticates the argument that in numerous instances the biblical text portrays the fact that some practices were borrowed from cultures of other nations in the ANE. In verse 15 , we read that whilst the couriers took the decree across the provinces, the king and Haman sat down to drink (Es 9:15). However, the plot for the genocide to exterminate the Jews turned against Haman (Es 7:10). The Jews assembled themselves in all the cities and provinces where they killed 5000 people including Haman's 10 sons (Es 9:1-10) as revenge for Haman's plot.

Of the accusations leveraged by Haman against Mordecai and the rest of the Jews, the question of intermarriage is not mentioned as being contentious. The biblical text forbade the Jews to have spouses from amongst pagan nations (Ex 23:3133; 34:12-16; Dt 7:2). A case of Esther becoming Queen to a pagan king, to which Buisman (2008:32) refers as: 'Esther, a beautiful Jewish girl, became concubine, then wife of the Persian Emperor ...' (see Es 2:15-16) and Mordecai's insistence on Esther seeking King Xerxes' intervention in order to save the Jews from a genocide instigated by Haman (Es 4:1-17) were in contravention with Yahweh's demand who was generally not pleased when his chosen people ran 
to pagan kings for help (cf. 2 Chr 16:7; 28:16-22; Hs 7:11-12; $8: 8-10)$. However, the Bible portrays the fact that Jewish men were married to women from neighbouring nations. Cases of Esther (a Jewess) becoming Queen to Emperor Xerxes (Es 2:15-18) and Ruth's (a Moabitess) marriage to Boaz - a Jew (Rt 4:9-15) serve as examples. Ruth herself - a member of the hated Moabite race - who was not required to 'enter the assembly of God' (Neh 13:1-3) was accepted as an Israelite and adopted Yahwism as her faith. In the New Testament, both Boaz and Ruth are traced to the ancestry of David and mentioned in the genealogy of Jesus Christ (Mt 1:5-6). Amongst King Solomon's 1000 wives were: the Pharaoh's daughter, including Moabite, Ammonite, Edomite, Sidonian and Hittite women (1 Ki 11:1). Moses' flight to Midian from Egypt led him to marry Zipporah, a Midianite woman (Ex 2:21). The name given to Moses' first child (Gershom) confirms this marriage to a foreigner (Ex 2:22). The matrimonial relationship of Esther (a slave) to Xerxes (Persian king) confirms Adamo's (2013:231) finding, which proposes that: 'In Israelite and Egyptian cultures a slave girl is automatically sexually available to her master' (see Ex 21:911). It is also reported that at Hazeroth, Moses married a Cushite woman (Nm 12:1). The book of Ezra (10:18-44) provides a list of men who married foreign women whilst in Babylonian exile. The given examples suggest that intermarriage between Jews and non-Jews - though not permissible - was feasible.

\section{Jewish revolt against Persia}

The readership may need to take note of the fact that Jewish revolt was not unique during the time of Esther at the time of the Persian Empire. For example, the Assyrian domination of the southern Levant is widely discussed (Aster 2017:28). Aster's (2017:28) statement that: 'During the second half of the reign of Ashurbanipal (669-631 BCE) the empire was weakened by revolts and over-extension, and gradually lost its grip on the region', reinforces the ideology that a revolt would weaken and crack 'empires' and 'kingdoms'. It is further stated that, 'Assyrian control over the region went from highly tenuous to non-existent' (Eph'al 1979:281-282). The Jewish revolt in Persia as depicted in the Book of Esther is likened by scholars to the Maccabean revolt. The following annunciation by Wetzel (2015) is in order:

... 2 Maccabees makes specific reference to a Jewish festival of the time known as 'the Day of Mordecai', to which the Maccabees attached the Day of Nicanor on the thirteenth of Adar, suggesting that the Jewish victory over Nicanor took place on the same day as the first of the two days of fighting described in the Esther stories (2 Macc. 15:35-36). The Day of Nicanor (instituted in 160 BCE) celebrated Judah Maccabee's victory over a Seleucid military commander who (according to Jewish tradition) spit at the Jerusalem Temple and some of its priests while threatening to burn down the Temple in response to the Maccabees' rededication of it and their attempts to restore Torah observance throughout the Promised Land (1 Macc. 7:25-38; a somewhat different account appears in 2 Macc. 15:1-39, serving as the culmination of the latter narrative). In the book of Maccabees (1 Macc. 7:39-49) the Jews turn to prayer, reminding God of his past judgments against threats to his
Temple and his people, and calling upon him to intervene here. This is followed by a profound Jewish military victory that, on its surface, displays no clear divine intervention (1 Macc. 7:39-49). (pp. 50-51)

The argument that king Xerxes lacked a strong administrative skill or rather that his leadership can be described as laissez-faire (see Chaudhry \& Javed 2012: 258-264) is identifiable in his response to a detailed report by Haman on national duty. In order to convince his superior about a security threat, Haman further pledged to pay a huge sum of money towards the extermination of the Jews. Although I disagree with the first part of Wetzel's (2015:49) statement that: 'Haman therefore represents a force of disorder within the Persian court in each version of the Esther story ...', the second part suggests that the Jews had become a lawless community in the provinces of the then world. In my view, although Haman might have intended to actually influence the killing of the Jews in all the provinces, it was in the best interest of king Xerxes to advise Haman on the best and alternative option of dealing with the Jewish lawlessness in the Empire. Haman was concerned about two critical issues with regard to Jewish immigrants: (1) their laws were different from those of every other people and (2) they had become lawless. As a consequence of these two factors, Haman foresaw the emergence of a revolt, which is mentioned in Esther 9. Let us examine the consequences of the Jewish lawlessness in the context of a revolt, which claimed 75000 deaths when the story came to an end (Wetzel 2015:4).

\section{Lawlessness and revolt}

Analysing Haman as a strategist and his patriotism to nationalism need not be taken for granted. Any government or cabinet minister who is expected to deliver or execute their constitutional mandate, especially with regard to safety and security of citizens (see Rugwiji 2018:1-19, 2020:125-142), would certainly be concerned when foreign nationals in a sovereign state become lawless; it is a fact. How to deal with such a scenario of lawlessness is another level to be considered by Cabinet. It appears that Haman felt unpleasant with lawlessness amongst the Jewish diaspora community. The practice of the Jewish diaspora community was in contrast to the teachings of the Torah which emphasised on the strict obedience to the laws, especially that of murder, 'You shall not kill' (Ex 20:13; see Rugwiji 2020:138). At Mount Sinai, Yahweh gave Israel the laws through Moses, which they would adhere to both in their journey of faith and as a nation when they finally settled in the Holy Land (see Dorsey 1991:321). For Rugwiji (2020:134) to write that: 'Reading Judges 17:6, indicates that there was some lawlessness in ancient Israel before the advent of the monarchy', indicates that Israel was accustomed to breaking the law even after the issuance of the Decalogue at Mount Sinai. For example, the Bar Kochba revolt occurred because the government enforced some restrictions and laws regulating how the Jews needed to conduct themselves. Grabbe (1994) concurred that: 
During this time, near the end of his reign, Hadrian imposed restrictions on Jewish activity, which were probably a result of the revolt rather than the cause of the revolt. (p. 602)

Thus, Rugwiji (2020) affirmed that:

The Decalogue (Ex. 20:3-17) given to Israel by Yahweh at Mount Sinai comprised a set of ten laws that were civil, ceremonial and moral in character by which Israel was going to live in the Promised Land. (p. 126)

At least before the establishment of the monarchy, lawlessness abounded because 'In those days there was no king in Israel; all the people did what was right in their own eyes' (Jdg 17:6; see also Rugwiji 2020:134). The laissez-faire type of leadership is also captured by Matthews (1991:67) who wrote that: 'Individual households and village assemblies administered justice and chose to listen or not to listen to the rallying calls of the judges'. One would also take cognisance of Rugwiji's (2020:137) assertion that: '... lawfulness (or lawlessness) remains implied when not adjudicated by a superior who has a constitutional mandate to do so'. Whilst it is stated elsewhere that: 'The biblical narratives and laws express esteem for life' (see Machingura \& Museka 2016:42) the Jewish diaspora community in Esther 3:8-15 no longer regarded it that way. Although the text presents Esther encouraging prayer and fasting in order to counteract the planned extermination, the Jews never waited for a response with regard to their prayers and fasting. One would therefore presuppose that the Jewish call to assemble for prayer and fasting (Es 4:16; 9:31) was actually a call to terrorism and plunder. This is so because after declaring a fast, the Jews went ahead and massacred 75000 people (Wetzel 2015:4). It is stated that the Jews celebrated at the killing of their enemies. In recent years, the readership might be reminded of terrorist groupings that have a 'religious' or 'Christian' perspective, such as Boko Haram of Nigeria (Abimbola 2010:95-108) and the Lord's Resistance Army of Uganda (Sturges 2011:76-79). Amongst the Muslims, there is what is commonly known as the 'Holy war' (Forbes 1965:131). All these religious groupings, cause unfathomed attacks on civilians and infrastructures in the name of the Divine. When the Jews of Esther's time massacred the Persians, questions are always raised about a loving Yahweh who would allow his 'chosen people' to emerge as 'terrorists'. Hence, Greer, Hilber and Walton (eds. 2018) could be right for affirming that for these religious groupings there is a God who works behind the scenes. It appears that Esther from the beginning did not act lawfully, which I suppose, Haman knew very well. The text makes it plain that Esther concealed her Jewish identity in order to win the heart of Xerxes in the beauty contest (Jobes 1999:20).

\section{Conclusion}

The present study argued that lawlessness by the Jewish diaspora community triggered genocide in the Persian Empire. Two very crucial aspects that Haman raised were: (1) the Jewish laws were different from the laws of other people in the Empire and (2) the Jews had become lawless.
An example was cited of Mordecai who disobeyed to bow down for Haman. The study discussed adherence to the law as the right thing to do and that any unlawful acts have a tendency of attracting violence. A disregard of the law tends to perpetuate a culture of rebellion, and the text of Esther 3:8-15 cannot be exonerated from it. Research has shown that any sport needs to be played according to the rules. Neglect of the rules may result in penalisation or complete ban from the sport. It was explored that Israel received from God through Moses at Mount Sinai a set of ceremonial, civil and moral laws by which they were going to live in the Promised Land. From that perspective, one would expect the Israelites to be a law-abiding citizenry. One would have looked up with expectation for this research to elaborate more on the specifics and the requirements of the Persian laws. ${ }^{3}$ However, Haman's report to King Xerxes suggests that Persia had its own laws that governed the entire Empire. According to Haman, these laws were not adhered to by the Jewish community. Although Haman's suggestion to the king of eliminating the Jews could be perceived by the pacifist readership as extremely harsh, one may also consider two scenarios that were at stake: (1) Haman's responsibility on the maintenance of the law and order in the empire and (2) security threat caused by the lawlessness of the Jews. The latter appeared to be the bone of contention by Haman because it was confirmed when the Jews revolted against the empire and killed thousands of Persians.

The notion of Haman's plan to exterminate all the Jewish immigrants because of Mordecai's disobedience towards Haman can further be problematised. The narrative in the Book of Esther highlights the notion that the 'crime' of Mordecai of being disrespectful to a minister of state meant that all immigrant Jews must be exterminated. It can be speculated that Haman interpreted Mordecai's negative attitude as representing the general feeling amongst the Jews aimed at undermining the Persian authority. The text does not present to the readership the criminal activities by the other Jews living in the Persian Empire as a whole. The Persian provincial leadership identified the general mood of Jewish conspiracy and rebellion. It is also natural for any security system (both ancient and modern) to be concerned when the leadership of a group opposed to the government starts moving around and telling their followers how bad the government is, especially when Mordecai demonstrated it openly. Usually, the opposition leadership is looked at with suspicion because of the influence they have on their followers. Haman might have regarded Mordecai as a dangerous person. For Haman to exterminate Mordecai and the ideology he stood for was a job 'half-done' because of the perceived seed of rebellion that Mordecai had sown amongst the rest of the Jews.

In my reading of Esther 3:8-15, Haman is presented as a strategist and patriot to nationalism in the narrative; he raises the question of unlawfulness on the part of Jewish immigrants

3.I have deliberately left out that discussion for another research because of space constraint. The focus at the moment in this present discourse is the lawlessness of the Jewish diaspora community as depicted in the book of Esther. 
dwelling in the empire. Although Haman was not living anymore to witness the massacre of the Persians by the Jews, one would suspect sheer pride on the part of king Xerxes to take stock of the casualties of the genocide without reflecting on Haman's foresight. One would also regard Xerxes' action as betrayal of his own people for both his failure to investigate allegations of lawlessness amongst the Jews and for allowing a militant response by the Jews themselves in retaliation to the planned extermination by the Persians. One would expect Xerxes as a leader to be resilient and prioritise national pride by protecting the nation against attack ahead of individual/personal interests. In my view, King Xerxes did not react in his right frame of mind. Or maybe, he did; however, his decision was consistent with what happened elsewhere in the then ancient world that kings would react or not react precisely on advice by their spouses. Some examples will suffice. King Ahab's seizure of Naboth's vineyard and the murder of Naboth by Ahab following the advice by the king's wife, Jezebel (1 Ki 21); in the New Testament we read that Pilate was hesitant to condemn Jesus to death by crucifixion because his wife had sent him a message that said: 'Have nothing to do with that righteous Man, because last night I suffered greatly in a dream because of Him' (Mt 27:19). Had the Jews not insisted, Pilate would have withdrawn from executing Jesus when the former contemplated on his wife's advice. However, Pilate finally complied with the Jewish demand by handing over Jesus to be crucified (Lk 23:25; see also Rugwiji 2020:137).

It can also be presupposed that the people that the Jews killed in Persia were civilians who were unarmed and untrained for war. It would be unreasonable for Xerxes to allow the Jews to continue massacring the Persians without the intervention of the Defence and Security system; such a stance would bring into disrepute Xerxes' leadership style. Given the fact that Xerxes allowed the genocide by the Jews as depicted in the narrative, the readership will then have another explanation that of the Deuteronomistic writer who always attempted to present the Jews as victorious over their enemies in every battle. It can further be problematised that Esther's call to fasting and praying by the Jews, was actually a call to a revolution, which she saliently orchestrated through deceitfulness. Such a stance about Esther's actions is perceived on the realisation that a call to fasting and praying can understandably be a quest for the reverse of Haman's plan, but certainly not an armed struggle as portrayed in the narrative. Nonetheless, Haman's proposition for an extermination of the Jews arose precisely from the latter's neglect and disobedience of the laws of the Persian Empire. Rebellious attitude of the Jewish immigrants in Persia was tantamount to military response because of its threat to defence and security.

\section{Acknowledgements Competing interests}

The author declares that they have no financial or personal relationships that may have inappropriately influenced them in writing this article.

\section{Author's contribution}

T.T.R. is the sole author of this research article.

\section{Ethical considerations}

This article followed all ethical standards for research without direct contact with human or animal subjects.

\section{Funding information}

This research received no specific grant from any funding agency in the public, commercial or not-for-profit sectors.

\section{Data availability}

Data sharing is not applicable to this article as no new data were created or analysed in this study.

\section{Disclaimer}

The views and opinions expressed in this article are those of the author and do not necessarily reflect the official policy or position of any affiliated agency of the author.

\section{References}

Abimbola, A., 2010, 'The Boko Haram uprising and Islamic revivalism in Nigeria', Africa Spectrum 45(2), 95-108. https://doi.org/10.1177/000203971004500205

Adamo, D.T., 2010, 'The Deuteronomist(s)' interpretation of exilic suffering in an African perspective', Old Testament Essays 23(1), 9-27.

Adamo, D.T., 2013, 'The nameless African wife of Potiphar and her contribution to ancient Israel', Old Testament Essays 26(2), 221-246.

Aster, S.Z., 2017, Reflections of Empire in Isaiah 1-39: Responses to Assyrian ideology, SBL Press, Atlanta, GA.

Beckman, G., 2013, 'Foreigners in the ancient Near East', Journal of the American Oriental Society 133(2), 203-215. https://doi.org/10.7817/jameroriesoci. 133.2.0203

Boshoff, W., 1991, 'God, gods and believers: Concepts of God in Israel's religious history', in H. Bosman, I. Gous \& I. Spangenberg (eds.), Plutocrats and paupers: Wealth and poverty in the Old Testament, pp. 170-188, Van Schaik, Pretoria.

Bremer, J., 2019, '“Land” as topic in Book of Psalms?', Old Testament Essays 32(2), 687-715. https://doi.org/10.17159/2312-3621/2019/v32n2a21

Buckley, S.L., 2000, Teachings on usury in Judaism, Christianity and Islam, Edwin Mellen Press, Lewiston.

Buisman, G., 2008, 'The "Day of the Lord" as reconciliation between judgment and salvation in the "Book of the Twelfth"', Master's dissertation, Stellenbosch University.

Chaudhry, A.Q. \& Javed, H., 2012, 'Impact of transactional and laissez-faire leadership style on motivation', International Journal of Business and Social Science 3(7) 258-264.

Dorsey, D.A., 1991, 'The law of Moses and of Christian: A compromise', Journal of the Evangelical Theological Society 34(3), 321-334.

Duguid, I., 2006, 'But they live happily ever after? The eschatology of the book of Esther', Westminster Theological Journal 68, 85-98.

Eph'al, I., 1979, 'Assyrian dominion in Palestine', in A. Malamat \& I. Eph'al (eds.), Political history of the age of the monarchies, pp. 276-289, Masada, Jerusalem.

Forbes, R.J., 1965, Studies in ancient technology, E.J. Brill, Leiden.

Gerleman, G., 1966, Studien zu Esther: Stoff - Struktur - Stil - Sinn, Biblische Studien, 48. Grabbe, L., 1994, Judaism from Cyrus to Hadrian, SCM,London.

Greer, J.S., Hilber, J.W. \& Walton, J.H. (eds.), 2018, Behind the scenes of the Old Testament, Baker Academic, Grand Rapids, MI.

Humphreys, W.L., 1973, 'A life-style for diaspora: A study of the tales of Esther and Daniel', Journal of Biblical Literature 92(2), 21-23. https://doi.org/10.2307/ 3262954

Isike, C. \& Isike, E., 2012, 'A socio-cultural analysis of African immigration to SA', Alternation 19(1), 93.

Jacobs, J., 2008, 'Characterizing Esther from the outset: The contribution of the story in Esther 2:1-20', Journal of Hebrew Scriptures 8, 16. https://doi.org/10.5508/ jhs.2008.v8.a16

Jobes, K.H., 1999, Esther: The NIV application commentary: From biblical text to contemporary life, Zondervan, Grand Rapids, MI. 
Jones, B.W., 1978, 'The so-called appendix to the book of Esther', Semitics 6, 36-43.

Klein, A., 2012, 'Hymn and history in Exod 15: Observations on the relationship between temple theology and Exodus narrative in the Song of the Sea', Zeitschrift für die Alttestamentliche Wissenschaft 124(4), 516-527. https://doi.org/10.1515/ zaw-2012-0036

Leemans, W.F., 1950, The old Babylonian merchant, Brill, Leiden.

Littman, R.J., 1975, 'The religious policy of Xerxes and the "book of Esther"', The Jewish Quarterly Review 65(3), 145-155. https://doi.org/10.2307/1454354

Machingura, F. \& Museka, G., 2016, “"Blood as the seat of life”: The blood paradox among Afro-Christians', Perichoresis 14(1), 41-62. https://doi.org/10.1515/perc2016-0003

Matthews, V.H., 1991, Manners and customs in the Bible: An illustrated guide to daily life in Bible times, rev. edn., Hendrickson Publishers, Peabody, MA.

Mckee, R.R., 2009, 'Women as heroes in a patriarchal society: The roles of Susanna, Esther and Judith', MA dissertation, Wake Forest University.

Reid, D., 2000, Ruth and Esther, Crossway Books, Leicester.

Römer, T., 2007, The so-called Deuteronomistic history, T \& T Clark, New York, NY.

Rugwiji, T., 2014, 'The salvific task of the suffering servant in Isaiah 42:1-7', Journal for Semitics 23(2i), 289-314. https://doi.org/10.25159/1013-8471/3492
Rugwiji, T., 2018, 'Rereading narratives of safety and security in ancient Israel from a pastoral perspective', Journal for Semitics 27(1), 1-19. https://doi.org/ 10.25159/1013-8471/3559

Rugwiji, T., 2020, 'The law and society in the Old Testament: Formulation and implementation of the law in ancient Israel', Old Testament Essays 33(1), 125-142. https://doi.org/10.17159/2312-3621/2020/v33n1a8

Sandelowski, M., 1991, 'Telling stories: Narrative research in qualitative approaches', Journal of Nursing Scholarship 23(3), 161-166. https://doi.org/10.1111/j.15475069.1991.tb00662.x

Snyman, G., 2014, 'The African and western hermeneutics debate: Mimesis, the book of Esther, and textuality', Old Testament Essays 25(3), 657-684.

Sturges, P., 2011, 'The role of spirit messages in African conflicts the case of Joseph Kony and the Lord's Resistance Army in Uganda', The Open Information Science Journal 3, 76-79. https://doi.org/10.2174/1874947X01103010076

Wetzel, T.A., 2015, 'Violence and the survival of Israel in the book of Esther', DTh thesis, Harvard University.

White, H., 1980, The value of narrative in the representation of reality, University of Illinois Press, Urbana, IL.

Zaeske, S., 2000, 'Unveiling Esther as a pragmatic radical reader', Philosophy and Rhetoric 33(3), 193-220. https://doi.org/10.1353/par.2000.0024 